\section{Cultural Management Practices for Commercial Tigernut Production in Southern Ontario, Canada}

\author{
Evan Elford ${ }^{1}$, Jim Todd ${ }^{1}$, Peter White ${ }^{2}$, Rachel Riddle ${ }^{2}$, \\ John O'Sullivan ${ }^{2}$, and Rene Van Acker ${ }^{2}$
}

AdDitional INDEX wORDs. aflatoxin, critical weed-free period, Cyperus esculentus var. sativus, fertility, irrigation, nutritional value

Summary. To foster development of Ontario commercial tigernut (Cyperus esculentus var. sativus) production, this study was conducted to identify cultural management practices that increase tuber yields. The agronomic practices of field preparation (hilled vs. not hilled), regular irrigation vs. natural rainfall, varying rates of nitrogen $(\mathrm{N})$ fertility, and early season weed management were evaluated. Irrigation had no significant impact on total fresh weight, dry weight, and marketable yield over 2 growing seasons. Similarly, yields from plants grown in hilled rows vs. flat beds over two seasons showed no significant differences. Tigernut yields did not show a response to increasing rates of $\mathrm{N}$ up to $150 \mathrm{~kg} \cdot \mathrm{ha}^{-1}$. A critical weedfree period of 3 weeks resulted in an $844 \%$ yield increase over the nonweeded control. Overall, the results indicate that in general, tigernut requires few inputs to produce a viable commercial yield under Ontario growing conditions.

$\mathrm{T}$ he tigernut (C. esculentus var. sativus), also known as chufa, is a species of sedge that produces a small edible tuber, typically referred to as a "nut." The tuber can be used for a variety of purposes: fresh or dried as a gluten-free snack (Bamishaiye and Bamishaiye, 2011), ground and used as a high-fiber wheat (Triticum aestivum), flour replacement (Adebayo-Oyetoro et al., 2017), juiced for production of a tigernut milk beverage known in Spain as "borchata de chufa" or simply horchata (Martín-Esparza and GonzálezMartínez, 2016) or yogurt (Akoma et al., 2004), and as a livestock feed replacement (Agbabiaka et al., 2013). Oil extracted from the tigernut is used in both culinary (Aljuhaimi et al., 2017; Linssen et al., 1988) and industrial applications (Ofoefule et al., 2013).

Received for publication 1 July 2020. Accepted for publication 10 Sept. 2020.

Published online 19 November 2020

${ }^{1}$ Ontario Ministry of Agriculture, Food and Rural Affairs, Simcoe Research Station, 1283 Blueline Road, Simcoe, ON, Canada N3Y 4N5

${ }^{2}$ Department of Plant Agriculture, University of Guelph, Simcoe Research Station, 1283 Blueline Road, Simcoe, ON, Canada N3Y 4N5

J.T. is the corresponding author. E-mail: jim.todd@ ontario.ca.

This is an open access article distributed under the CC BY-NC-ND license (https://creativecommons.org/ licenses/by-nc-nd/4.0/).

https://doi.org/10.21273/HORTTECH04682-20
In response to inquiries from local processors interested in developing a domestic source of tigernuts, this project was initiated to determine if tigernut could be successfully grown in southern Ontario, Canada. Although tigernut is closely related to a common weed found in Ontario known as yellow nutsedge (C. esculentus), very little agronomic information exists for growing the commercially cultivated tigernut variety in temperate climates such as southern Ontario. Most published agronomic information is from Spain, with much of the research focusing on water management of the tigernut crop (Pascual-Seva et al., 2018). Tigernut is traditionally planted in ridged rows with furrow irrigation (Pascual-Seva et al., 2013). Studies to investigate the basic agronomic requirements of irrigation, field preparation, weed control, and nitrogen
(N) fertility were conducted over two growing seasons to determine which, if any, produced higher yields of tigernut tubers.

\section{Materials and methods}

Agronomic field trials were conducted at the Simcoe Research Station (SRS), located in Simcoe, ON, Canada (lat. $42^{\circ} 51^{\prime} \mathrm{N}$, long. $80^{\circ} 16^{\prime} \mathrm{W}$ ) in 2017 and 2018. The soil at SRS is a fine sandy loam, with an organic matter content of $1.2 \%$ and a $\mathrm{pH}$ of 6.7 (Hohner and Presant, 1988).

The trials were established in late May to early June depending on year, with harvest occurring in late October (Table 1). Each planting site was used for only a single growing season. All experiments followed a randomized complete block design with four replicates. Each replicate consisted of three rows, each $5 \mathrm{~m}$ in length, with samples harvested from the center $3 \mathrm{~m}$ of the middle row. For all trials, except the $\mathrm{N}$ trial, calcium ammonium nitrate $(27 \mathrm{~N}-0 \mathrm{P}-0 \mathrm{~K})$ was applied before planting at a rate of $100 \mathrm{~kg} \cdot \mathrm{ha}^{-1}$ $\mathrm{N}$. Tigernut tubers originated from Niger and were purchased from Tigernuts Traders (Valencia, Spain). Tubers were planted using a plate planter (model 71 Flexi-Planter; John Deere, Moline, IL). Planting was done at an in-row spacing of 10 $\mathrm{cm}$ and a between row spacing of 60 $\mathrm{cm}$, giving a stand density of 166,665 plants/ha.

Nitrogen trial. Calcium ammonium nitrate was applied at 0,50 , 100 , or $150 \mathrm{~kg} \cdot \mathrm{ha}^{-1} \mathrm{~N}$. Fertilizer was applied as a split application, $75 \%$ applied before planting and mechanically incorporated into the soil and $25 \%$ hand applied and raked in as a side dress during the last week of July.

\begin{tabular}{lllc}
\hline $\begin{array}{l}\text { Units } \\
\text { To convert U.S. to SI, } \\
\text { multiply by }\end{array}$ & U.S. unit & SI unit & $\begin{array}{l}\text { To convert SI to U.S., } \\
\text { multiply by }\end{array}$ \\
\hline 0.4047 & acre $(\mathrm{s})$ & $\mathrm{ha}$ & 2.4711 \\
0.3048 & $\mathrm{ft}$ & $\mathrm{m}$ & 3.2808 \\
3.7854 & gal & $\mathrm{L}$ & 0.2642 \\
2.54 & inch $(\mathrm{es})$ & $\mathrm{cm}$ & 0.3937 \\
25.4 & inch $(\mathrm{es})$ & $\mathrm{mm}$ & 0.0394 \\
1.1209 & $\mathrm{lb} / \mathrm{acre}$ & $\mathrm{kg} \cdot \mathrm{ha}^{-1}$ & 0.8922 \\
1 & $\mathrm{ppb}$ & $\mu \mathrm{g} \cdot \mathrm{kg}^{-1}$ & 1 \\
0.001 & $\mathrm{ppm}$ & $\mathrm{g} \cdot \mathrm{kg}^{-1}$ & 1000 \\
1 & $\mathrm{ppm}$ & $\mathrm{mg} \cdot \mathrm{kg}^{-1}$ & 1 \\
6.8948 & $\mathrm{psi}$ & $\mathrm{kPa}$ & 0.1450 \\
$\left({ }^{\circ} \mathrm{F}-32\right) \div 1.8$ & ${ }^{\circ} \mathrm{F}$ & ${ }^{\circ} \mathrm{C}$ & $\left({ }^{\circ} \mathrm{C} \times 1.8\right)+32$
\end{tabular}


Table 1. Length of growing season, growing degree days (GDD) base $10{ }^{\circ} \mathrm{C}\left(50.0{ }^{\circ} \mathrm{F}\right)$, accumulated precipitation, and total irrigation water applied data for tigernuts grown at the Simcoe Research Station, Simcoe, ON, Canada from 2017 to 2019.

\begin{tabular}{lcccccc}
\hline Yr & $\begin{array}{c}\text { Planting } \\
\text { date }\end{array}$ & $\begin{array}{c}\text { Harvest } \\
\text { date }\end{array}$ & $\begin{array}{c}\text { Season } \\
\text { length }(\mathbf{d})\end{array}$ & $\begin{array}{c}\text { Accumulated } \\
\text { GDD }\end{array}$ & $\begin{array}{c}\text { Accumulated } \\
\text { precipitation }(\mathbf{m m})^{\mathbf{z}}\end{array}$ & $\begin{array}{c}\text { Total irrigation water } \\
\text { applied }(\mathbf{m m})\end{array}$ \\
\hline 2017 & 6 June & 20 Oct. & 137 & 1,248 & 288 & 138 \\
2018 & 6 June & 23 Oct. & 140 & 1,292 & 457 & 80 \\
2019 & 24 May & 29 Oct. & 159 & 1,288 & 625 & \\
\hline
\end{tabular}

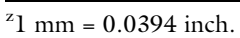

SUPPLEMENTAL IRRIGATION TRIAL. Tigernut plants grown in nonirrigated plots (rainfall only) were compared with irrigated plots. A trickle irrigation system using municipal water was used to provide supplemental irrigation to ensure the crop received a seasonal average of 20 to $25 \mathrm{~mm}$ of water per week. Drip tape (6 mil wall thickness) was placed in the center of each row of tigernut, and emitters were spaced at $15-\mathrm{cm}$ intervals, with each emitter delivering $0.84 \mathrm{~L} \cdot \mathrm{h}^{-1}$ at a pressure of $69 \mathrm{kPa}$.

Field preparation trial. Tigernut tubers were planted into a flat seed bed vs. hilled rows. Given the relatively small plot size, shovels were used to manually hill the soil to cover the bottom one-third of the young plants $(9 \mathrm{~cm}$ tall $)$, in the hilled row treatments, 2 weeks after seedling emergence. This process was repeated a second time, $\approx 6$ weeks after seedling emergence when the plants were 18 to $21 \mathrm{~cm}$ in height.

Critical Weed-free period. Four treatments were evaluated. A weedy control with no removal of weeds throughout the season after planting, and plots that were hand weeded on weekly intervals for 1,2 , or 3 weeks after seedling emergence.

Harvest. The tigernuts were harvested in October. Immediately before harvest, the top growth was removed using a sickle mower (BCS America, Oregon City, OR), and the center row of each replicate plot was undercut at a depth of $20 \mathrm{~cm}$ with a tractor-mounted blade. The center $3 \mathrm{~m}$ of the middle row of each plot was then hand harvested. Excess soil was removed in the field, nuts were placed in bins, and stored for no more than 2 weeks at $4{ }^{\circ} \mathrm{C}$ until cleaned and processed. Each sample was hand cleaned to remove excess dirt and plant material. Nuts were placed into mesh bags and thoroughly washed using a cement mixer to remove all soil. Fresh weights were recorded, and sub-samples dried in an oven at $70{ }^{\circ} \mathrm{C}$ for $72 \mathrm{~h}$. Sizing of fresh nuts was completed by sifting through a $1.25 \times 1.25-\mathrm{cm}$ mesh screen. Visual inspection of a random 100 marketable (larger than $1.25 \mathrm{~cm}$ diameter) nut sample was done to record insect feeding damage. Final marketable dry weights were recorded for tigernuts that were larger than $1.25 \mathrm{~cm}$ diameter and had no insect feeding damage.

Data analysis. All data were analyzed using the analysis of variance procedure of Statistix 9 (Analytical Software, Tallahassee, FL). Where the results of this analysis showed significant year by treatment interactions, data for each year were analyzed and presented separately. All effects were considered significant at $P \leq$ 0.05 using Tukey's test for multiple means comparisons. Linear regression analysis was used to analyze the data from the $\mathrm{N}$ fertility study.

\section{Results and discussion}

The details of each growing season are presented in Table 1. Season lengths ranged from 137 to $159 \mathrm{~d}$. The accumulated growing degree days (GDD) were calculated using $10{ }^{\circ} \mathrm{C}$ base temperature. The conflicting results between the 2017 and 2018 data for the $\mathrm{N}$ trial prompted a third year of trials to be conducted in 2019 for $\mathrm{N}$ only. GDD were similar for the three seasons, with the lowest in 2017 (1248.0) and highest in 2018 (1291.8). The driest summer was in 2017 , recording only $287.6 \mathrm{~mm}$ of precipitation, whereas 2019 had more than twice the rainfall $(624.8 \mathrm{~mm})$ (Table 1).

The effect of irrigation on tigernut yield was evaluated by comparing nonirrigated plots, which received rainfall only, with those receiving supplemental irrigation (municipal water) plus rainfall up to an average total of 20 to $25 \mathrm{~mm}$ of water per week over the course of the growing season. In 2018, the rainfed plots received $169.2 \mathrm{~mm}$ more rainfall than in 2017, but irrigation had no significant impact on yield over two growing seasons (Table 2). Total fresh weight, dry weight, and marketable yields were statistically similar (Table 2 ), indicating that tigernut does not require supplemental irrigation to produce a viable crop in Ontario. The lack of difference in marketable dry weight yield between the irrigated and nonirrigated treatments (3237 vs. $3447 \mathrm{~kg} \cdot \mathrm{ha}^{-1}$ ) suggests that additional irrigation did not result in greater production of tigernuts larger than $1.25 \mathrm{~cm}$ diameter. Tigernut is traditionally planted in ridged rows with furrow irrigation. Previous work showed less water was required to produce similar yields if surface drip irrigation was applied to ridges with a plant row vs. flat raised beds containing two rows of plants that were watered using flood irrigation (Pascual-Seva et al., 2013).

A comparison of fresh, dry, and marketable tigernut yields from plants grown in hilled rows vs. not hilled beds over two seasons showed no significant differences (Table 3 ). It was observed that removing the vegetative top growth by mowing before harvesting the tubers was more easily accomplished on the hilled rows.

The critical weed-free period is defined as the time during which weed removal from the crop prevents significant yield loss. Previous studies have established the critical weed-free period for many crops, including canola (Brassica napus), carrot (Daucus carota), and peanut (Arachis hypogaea) (Everman et al., 2008; Martin et al., 2001; Swanton et al., 2010). Weed control was shown to have a significant impact on final tigernut yield (Table 4). Removing weeds for as little as 1 week after seedling emergence resulted in a $394 \%$ increase in total fresh weight of tubers when compared with the nonweeded 
Table 2. Average total and marketable yields of tigernuts as affected by supplemental irrigation at the Simcoe Research Station, Simcoe, ON, Canada in 2017 and 2018.

\begin{tabular}{lccc}
\hline & Total fresh $\mathbf{w t}^{\mathbf{z}}$ & Total dry wt $^{\mathbf{z}}$ & Marketable dry wt $^{\mathbf{z}}$ \\
\cline { 2 - 4 } Applied water source & \multicolumn{3}{c}{$\left(\mathbf{k g} \cdot \mathbf{h a} \mathbf{a}^{-\mathbf{1}}\right)^{\mathbf{y}}$} \\
\hline Rainfall only & $10,042 \mathrm{a}$ & $5,826 \mathrm{a}$ & $3,447 \mathrm{a}$ \\
Drip irrigation & $9,156 \mathrm{a}$ & $5,218 \mathrm{a}$ & $3,237 \mathrm{a}$ \\
\hline
\end{tabular}

${ }^{\mathrm{z}}$ Treatment-by-year interaction was not significant $(P=0.652,0.708$, and 0.455 , respectively). Within columns, values followed by the same letter are not significantly different at the $P \leq 0.05$ level using Tukey's test for multiple means comparisons.

${ }^{\mathrm{y}} 1 \mathrm{~kg} \cdot \mathrm{ha}^{-1}=0.8922 \mathrm{lb} / \mathrm{acre}$

Table 3. Average total and marketable yields of tigernuts as affected by row hilling, at the Simcoe Research Station, Simcoe, ON, Canada in 2017 and 2018.

\begin{tabular}{lccc}
\hline & Total fresh wt & Total dry wt & Marketable dry wt $^{\mathrm{z}}$ \\
\cline { 2 - 4 } Field preparation method & \multicolumn{3}{c}{$\left(\mathbf{k g} \cdot \mathbf{h a} \mathbf{a}^{-\mathbf{1}}\right)^{\mathbf{y}}$} \\
\hline Hilled & $9,656 \mathrm{a}$ & $5,392 \mathrm{a}$ & $3,212 \mathrm{a}$ \\
Not hilled & $7,921 \mathrm{a}$ & $4,549 \mathrm{a}$ & $2,805 \mathrm{a}$ \\
\hline
\end{tabular}

${ }^{\mathrm{z}}$ Treatment-by-year interaction was not significant $(P=0.291,0.344$, and 0.843 , respectively). Within columns, values followed by the same letter are not significantly different at the $P \leq 0.05$ level using Tukey's test for multiple means comparisons.

${ }^{\mathrm{y}} 1 \mathrm{~kg} \cdot \mathrm{ha}^{-1}=0.8922 \mathrm{lb} /$ acre

Table 4. Average total and marketable yields of tigernuts as affected by early season weeding at the Simcoe Research Station, Simcoe, ON, Canada in 2017 and 2018.

\begin{tabular}{|c|c|c|c|c|}
\hline \multirow[b]{3}{*}{ Weed-free period (weeks) } & Total fresh $w^{\mathrm{z}}$ & Total dry $w^{z}$ & \multicolumn{2}{|c|}{ Marketable dry wt } \\
\hline & \multicolumn{4}{|c|}{$\left(\mathrm{kg} \cdot \mathrm{ha}^{-1}\right)^{\mathrm{y}}$} \\
\hline & & & 2017 & 2018 \\
\hline Nonweeded control & $928 \mathrm{c}$ & $575 \mathrm{c}$ & $551 \mathrm{c}$ & $108 \mathrm{~b}$ \\
\hline 1 & $3,657 \mathrm{~b}$ & $2,059 \mathrm{~b}$ & $1,902 \mathrm{bc}$ & $387 \mathrm{~b}$ \\
\hline 2 & $6,151 \mathrm{a}$ & 3,478 a & $2,873 \mathrm{ab}$ & $1,003 \mathrm{ab}$ \\
\hline 3 & 7,832 a & 4,332 a & $3,671 \mathrm{a}$ & $1,323 \mathrm{a}$ \\
\hline
\end{tabular}

${ }^{z}$ Treatment-by-year interaction was not significant for total fresh and dry wt yields $(P=0.269$ and 0.377 , respectively). Within columns, values followed by the same letter are not significantly different at the $P \leq 0.05$ level using Tukey's test for multiple means comparisons.

${ }^{\mathrm{y}} \mathrm{l} \mathrm{kg} \cdot \mathrm{ha}^{-1}=0.8922 \mathrm{lb} /$ acre.

control. Although there was no significant difference in total fresh weight between the 2 - and 3 -week weeding treatments, keeping the plots weed free for 3 weeks resulted in an $844 \%$ yield increase over the nonweeded control. Three weeks after seedling emergence, the crop canopy was sufficiently large to deter weed growth through shading. A significant treatment-by-year interaction for marketable yield was due to a difference in tigernut size, not damage from insect feeding (data not shown), as damage ratings were similar in both seasons. Even though the marketable yields differed between 2017 and 2018, the trend of early season weed control increasing yield was similar in both years (Table 4).

The effect of $\mathrm{N}$ fertility on tigernut yield was assessed using applied rates of $0,50,100$, or $150 \mathrm{~kg} \cdot \mathrm{ha}^{-1} \mathrm{~N}$ (Table 5). In 2017, there was a weak linear increase in total fresh, dry, and marketable yield with increased $\mathrm{N}$, but the $R^{2}$ values determined by linear regression were low $(0.3104$, 0.3103 , and 0.265 , respectively). The data from the 2018 season showed no relationship between yield and applied $\mathrm{N}$ rate for total fresh, dry, and marketable yield $\left(R^{2}\right.$ values of $0.0462,0.0390$, and 0.0048 , respectively). The data from 2019 were similar to data collected in 2018 , with $R^{2}$ values for total, dry, and marketable yield of $0.0096,0.0096$, and 0.0752 , respectively. There was no significant treatment-by-year interaction, indicating the results were consistent year to year. Within each year, the yield of tigernuts did not increase as the amount of applied $\mathrm{N}$ increased up to $150 \mathrm{~kg} \cdot \mathrm{ha}^{-1} \mathrm{~N}$. Although higher rates of $\mathrm{N}$ ( 250 to $400 \mathrm{~kg} \cdot \mathrm{ha}^{-1}$ ) were used in earlier studies, these also showed tuber production did not increase as the amount of added $\mathrm{N}$ increased (Pascual et al., 2000). Other research done by growing tigernut indoors in pots led the author to suggest, at least for pot-grown plants, that limited practical response to nutrient application can be expected for tigernut (Johnson, 2011). Tuber crops are known to be potassium $(\mathrm{K})$ exigent, but the effect of $K$ on tigernut tuber yield was not studied. Soil tests show the average $\mathrm{K}$ value for the production sites was $\approx 47 \mathrm{~kg} \cdot \mathrm{ha}^{-1}$ (105 ppm), which is in the normal range for vegetable crops like sugar beet (Beta vulgaris) and potato (Solanum tuberosum), grown on mineral soils in Ontario (Ontario Ministry of Agriculture, Food and Rural Affairs, 201011). Proximate analysis (Table 6) indicates the tigernut tubers were not deficient in $\mathrm{K}$.

Previous studies have shown tigernut grown outside of North America can be contaminated with aflatoxins, a naturally occurring and toxic group of secondary metabolites produced by Aspergillus fungi (Sebastià et al., 2010). The allowable limit of total aflatoxin in nuts and nut products in Canada is 15 ppb (Canadian Food Inspection Agency, 2019). Sixteen separate samples of tigernut tubers from the 2017 growing season were tested for the presence of total aflatoxin using enzyme-linked immunosorbent assay by A\&L Canada Laboratories (London, $\mathrm{ON}$, Canada). At a detection limit of $5 \mathrm{ppb}$, all samples were free from the presence of aflatoxin.

A chemical analysis of tigernuts harvested in 2017 was also done by A\&L Canada Laboratories. In general, the results showed agreement with previous chemical analysis of tigernuts grown in Nigeria (Aljuhaimi et al., 2017; Ekeanyanwu and Ononogbu, 2010; Gambo and Da'u, 2014; Temple et al., 1990). The primary components of crude protein, fiber, carbohydrate, fat, and ash contents are very similar, with the main differences occurring in the minor components (Table 6). Calcium, magnesium, sodium, and iron were more abundant in tigernuts grown in southern Ontario $(1938 \%, 21,428 \%$, $685 \%$, and $531 \%$, higher, 
Table 5. Linear regression analysis results for the response of average tigernut total fresh, dry, and marketable yields to varying amounts of nitrogen fertilizer at the Simcoe Research Station, Simcoe, ON Canada in 2017,2018, and 2019.

\begin{tabular}{|c|c|c|c|}
\hline \multirow[b]{2}{*}{ Yr } & Total fresh wt & Total dry wt & Marketable dry wt \\
\hline & \multicolumn{3}{|c|}{$\left(\mathrm{kg} \cdot \mathrm{ha}^{-1}\right)^{\mathrm{z}}$} \\
\hline 2017 & $\begin{array}{l}R^{2}=0.310 \\
\mathrm{y}=4023.57+(\mathrm{N} \times 22.972) \text { significant } \\
\quad \text { at } P \leq 0.05\end{array}$ & $\begin{array}{l}R^{2}=0.310 \\
\mathrm{y}=2358.12+(\mathrm{N} \times 12.847) \text { significant } \\
\quad \text { at } P \leq 0.05\end{array}$ & $\begin{array}{l}R^{2}=0.265 \\
\mathrm{y}=1572.39+(\mathrm{N} \times 9.0924) \text { significant } \\
\quad \text { at } P \leq 0.05\end{array}$ \\
\hline 2018 & $R^{2}=0.046$ not significant at $P \leq 0.05$ & $R^{2}=0.039$ not significant at $P \leq 0.05$ & $R^{2}=0.005$ not significant at $P \leq 0.05$ \\
\hline 2019 & $R^{2}=0.01$ not significant at $P \leq 0.05$ & $R^{2}=0.01$ not significant at $P \leq 0.05$ & $R^{2}=0.075$ not significant at $P \leq 0.05$ \\
\hline
\end{tabular}

${ }^{\mathrm{z}} 1 \mathrm{~kg} \cdot \mathrm{ha}^{-1}=0.8922 \mathrm{lb} / \mathrm{acre}$.

Table 6. Proximate analysis of tigernuts grown at the Simcoe Research Station, Simcoe, ON, Canada in 2017 compared with a previous chemical analysis of tigernuts grown in Nigeria (Temple et al., 1990). Tigernuts were analyzed at a moisture content of $0 \%$.

\begin{tabular}{|c|c|c|}
\hline \multirow[b]{2}{*}{ Component $^{\mathrm{z}}$} & Simcoe & Nigeria \\
\hline & \multicolumn{2}{|c|}{$\begin{array}{c}\text { mean } \pm \text { SD (per kilogram } \\
\text { dry wt) }]^{\mathrm{z}}\end{array}$} \\
\hline Crude protein $(\mathrm{g})$ & 65.1 & $70.0 \pm 7.3$ \\
\hline Acid detergent fiber + neutral detergent fiber $(\mathrm{g})$ & 39.0 & $55.0 \pm 8.1$ \\
\hline Calcium $(\mathrm{mg})$ & 500 & 25.8 \\
\hline Potassium (mg) & 6,900 & 148.2 \\
\hline Magnesium (mg) & 900 & 4.2 \\
\hline Iron $(\mathrm{mg})$ & 114.1 & 21.6 \\
\hline Sodium $(\mathrm{mg})$ & 100 & 14.6 \\
\hline Sugars, starches, organic acids, and pectin $(\mathrm{g})$ & 575.7 & $600.0 \pm 9.8$ \\
\hline Crude fat $(\mathrm{g})$ & 264.9 & $257.0 \pm 23.6$ \\
\hline $\operatorname{Ash}(\mathrm{g})$ & 26.7 & $18.6 \pm 1.4$ \\
\hline
\end{tabular}

${ }^{\mathrm{z}} 1 \mathrm{~g} \cdot \mathrm{kg}^{-1}=1000 \mathrm{ppm}, 1 \mathrm{mg} \cdot \mathrm{kg}^{-1}=1 \mathrm{ppm}$.

respectively). The ash content was higher in Ontario-grown tigernuts as well, most likely because these tigernuts contained $46,559 \%$ more potassium than the Nigerian samples and potassium salts are a major contributor to ash content. The high levels of crude lipid and carbohydrates typically found in tigernuts give them significant nutritional value.

To date, tigernut has not been commercially cultivated in southern Ontario. This research was done to provide information on the basic agronomic requirements for growth. The results indicate that in general, tigernut requires few inputs to produce a viable yield under Ontario growing conditions. Interestingly, this cultivar displayed no cold tolerance when grown in Ontario. Over 3 years and three different production sites, no volunteers were found growing the year following the production year. It was also observed that storing harvested tubers at 0 to $2{ }^{\circ} \mathrm{C}$ for the winter months reduced the germination rate to a maximum of $13 \%$ (E. Elford, unpublished data). Previous studies in Spain showed similar per plant tuber fresh weight yields to those obtained in Ontario (Pascual-Seva, et al., 2013). Supplemental irrigation at 20 to $25 \mathrm{~mm}$ per week, hilling, and the application of up to $150 \mathrm{~kg} \cdot \mathrm{ha}^{-1} \mathrm{~N}$ did not increase the total fresh weight, dry weight, or marketable weight of tigernuts when compared with the control treatments. Similar to other crops (Everman et al., 2008; Martin et al., 2001; Swanton et al., 2010 ), tigernut yield is significantly impacted by early season weed pressure. The results to date indicate that a critical weed-free period of 2 to 3 weeks is required for preventing yield loss. Future establishment of a commercial tigernut industry in southern Ontario will require further refinement of agronomic practices (e.g., planting density, additional fertility studies) and the development of harvest/postharvest equipment and practices.

\section{Literature cited}

Adebayo-Oyetoro, A., O. Ogundipe, F. Lofinmakin, F. Akinwande, D. Aina, and S. Adeyeye. 2017. Production and acceptability of chinchin snack made from wheat and tigernut (Cyperus esculentus) flour. Cogent Food Agr. 3(1):1282185.

Agbabiaka, L.A., F.N. Madubuike, B.U. Ekenyem, and B.O. Esonu. 2013. Effect of feeding different levels of tigernut (Cyperus esculentus L.) meal on growth of broiler chicks. Amer. J. Exp. Agr. 3(4):996-1004

Akoma, O., U. Elekwa, A. Afodunrinbi, and G. Onyeukwu. 2004. Yogurt from coconut and tigernuts. J. Food Technol. Afr. 5(4):132-134

Aljuhaimi, F., Ş. Şimşek, and M. Özcan. 2017. Comparison of chemical properties of taro (Colocasia esculenta L.) and tigernut (Cyperus esculentus) tuber and oils. J. Food Process. Preserv. 42:e13534.

Bamishaiye, E.I. and O.M. Bamishaiye. 2011. Tiger nut: As a plant, its derivatives and benefits. Afr. J. Food Agr. Nutr. Dev. $11(5): 5157-5170$.

Canadian Food Inspection Agency. 2019. Aflatoxins in selected corn products, nuts, nut products, raisins, cocoa powder, chili powder and paprika - 1 Apr. 2012 to 31 Mar. 2013. 12 Aug. 2020. <https://www. inspection.gc.ca/food-safety-for-industry/ chemical-residues-microbiology/foodsafety-testing-bulletins/2019-06-12/ aflatoxins/eng/1557171015830/ 1557171066945>.

Ekeanyanwu, R. and C. Ononogbu. 2010. Nutritive value of Nigerian tigernut (Cyperus esculentus L.). Agron. J. 5(5):297302.

Everman, W., I. Burke, S. Clewis, W. Thomas, and J. Wilcut. 2008. Critical period of grass vs. broadleaf weed interference in peanut. Weed Technol. 22(1):68-73.

Gambo, A. and A. Da'u. 2014. Tiger nut (Cyperus esculentus): Composition, products, uses and health benefits - A review. Bayero J. Pure Appl. Sci. 7(1):56-61. 
Hohner, B. and T. Presant. 1988. Soils of the horticultural experimental station Simcoe. Ontario Inst. Pedol. Publ. 89-3.

Johnson, A. 2011. Determination of optimal cropping system for white-tailed deer in the southeast and chufa response to nutrient additions. Auburn Univ., Auburn, Alabama, MSc Thesis, 12 Aug. 2020. <http://hdl.handle.net/10415/ 2517>.

Linssen, J., G. Kielman, J. Cozijnsen, and W. Pilnik. 1988. Comparison of chufa and olive oils. Food Chem. 28(4):279-285.

Martin, S.G., R. Van Acker, and L.F. Friesen. 2001. Critical period of weed control in spring canola. Weed Sci. 49(3):326-333.

Martín-Esparza, E. and C. GonzálezMartínez. 2016. Horchata de chufa: A traditional Spanish beverage with exceptional organoleptic, nutritive, and functional attributes, p. 371-375. In: K. Kristbergsson and S. Ötles (eds.). Func- tional properties of traditional foods: Integrating food science and engineering knowledge into the food chain. Vol. 12. Springer, Boston, MA.

Ofoefule, A.U., C.N. Ibeto, U.C. Okoro, and O.D. Onukwuli. 2013. Biodiesel production from tigernut (Cyperus esculentus) oil and characterization of its blend with petro-diesel. Phys. Rev. Res. Intl. 3(2):145-153.

Ontario Ministry of Agriculture, Food and Rural Affairs. 2010-11. Vegetable production recommendations. OMAFRA Publ. 363.

Pascual, B., J.V. Maroto, S. Lopez-Galarza, A. Sanbautista, and J. Alagarda. 2000. Chufa (Cyperus esculentus L. var. sativus Boeck.): An unconventional crop. Studies related to applications and cultivation. Econ. Bot. 54(4):439-448.

Pascual-Seva, N., A. San Bautista, S. Lopez-Galarza, J. Maroto, and B. Pascual. 2013. Saving water in chufa cultivation by using flat raised beds and drip irrigation. J. Irrig. Drain. Eng. 140(2):04013008.

Pascual-Seva, N., A. San Bautista, S. Lopez-Galarza, J. Maroto, and B. Pascual. 2018. Influence of different drip irrigation strategies on irrigation water use efficiency on chufa (Cyperus esculentus L. var. sativus Boeck.) crop. Agr. Water Mgt. 208:406-413.

Sebastià, N., C. Soler, J. Soriano, and J. Mañes. 2010. Occurrence of aflatoxins in tigernuts and their beverages commercialized in Spain. J. Agr. Food Chem. 58(4):2609-2612.

Swanton, C., J. O'Sullivan, and D. Robinson. 2010. The critical weed-free period in carrot. Weed Sci. 58(3):229-233.

Temple, V., T. Ojobe, and M. Kapu. 1990. Chemical analysis of tiger nut (Cyperus esculentis). J. Sci. Food Agr. 50(2):261-263. 